looking at isolated scraps of a regional phenomenon generally concealed by the sea around the continental margin? In view of the very large positive gravity anomaly known in Cyprus, it would be of great interest to get observations from Qizil Dagh and the Canaries and compare them.

The formation of pillow-lavas seems to mean no more than the discharge of a flow into the sea, not necessarily into deep water; on the northern side of the Troödos there is certainly one example of a flow a few feet thick with marked columnar jointing merging into pillows without jointing, presumably as it moved off-shore.

JOHANNESBURG.

D. W. BisHopr.

22nd July, 1958.

\title{
PELAGIC FORAMINIFERA IN THE TERTIARY OF VICTORIA
}

SIR, - I was extremely interested to read the recent account (July-August, 1958) by Alan Carter of the planktonic foraminifera of the Victorian Tertiary.

For the last two years I have been working on foraminifera from a $1,200 \mathrm{ft}$. sequence of marine rocks from the Lakes Entrance Oil Shaft, Gippsland, Victoria. Samples were collected at every 4 feet, below 212 feet, by Miss I. Crespin, and were made available to me by the Bureau of Mineral Resources, Canberra.

I would like to comment on some of the ranges of some of the foraminifera referred to in Carter's paper and compare them briefly with those found in the shaft.

(1) The initial appearance of Globigerina ciperoensis ciperoensis Bolli is 64 feet above that of Globoquadrina dehiscens (Chapman, Parr, and Collins) and its extinction is 172 feet before the initial appearance of Orbulina universa d'Orbigny. It seems, therefore, to have a shorter range than that indicated in his Table 1 (p. 299), more comparable to that recorded in Trinidad (Bolli, 1957). The subspecies Globigerina ciperoensis angustisuturalis Bolli has a still shorter range.

(2) Globigerinoides bispherica Todd appears 172 feet after the initial appearance of Globigerinoides triloba Reuss, and 64 feet before that of Orbulina universa d'Orbigny. Again, it is suggested that this species has a much shorter range than Dr. Carter indicates. It is sometimes confused with the large forms of Globigerinoides triloba Reuss immatura Le Roy, but the emended description of Blow (1956) does help in its diagnosis.

(3) Globigerina ampliapertura Bolli is found before the appearance of Globigerina ciperoensis ciperoensis Bolli, and prior to the publication of Bolli's paper (1957) this Upper Oligocene/Lower Miocene form was called Globigerina apertura Cushman. This latter name is now restricted to forms which occur in the Middle and Upper Miocene only.

(4) Globigerinoides rubra d'Orbigny is very rare, occurring in only four samples scattered over 144 feet.

(5) Orbulina universa d'Orbigny appears 20 feet after Candorbulina universa Jedlitschka (= Orbulina suturalis Bronnimann) and Orbulina bilobata (d'Orbigny) (= Biorbulina bilobata Blow) 12 feet later. Blow's (1956) evolutionary series is present in all its detail and it may be of some interest to note that the evolution of Orbulina universa d'Orbigny from Globigerinoides triloba (Reuss) takes place in 236 feet of marly Bryozal limestone.

(6) Globorotalia barisaensis Le Roy occurs, but the keeled Globorotalia fohsi lineage is not present, which seems to confirm Carter's views (p. 302). Probable specimens of Catapsydrax dissimilis (Cushman and Bermudez) and Globigerinatella insueta Cushman and Stainforth occur in the lower part of the shaft but are too rare to be considered as zone fossils. The important fact is that their ranges seem to correspond to those in Trinidad (Bolli, 1957).

It is hoped to publish shortly a detailed account of the ranges of some 
fifty species and subspecies of planktonic foraminifera found in the shaft as a further contribution to the intercontinental correlation of the Tertiary rocks.

\section{REFERENCES}

Blow, W. H., 1956. Origin and Evolution of the Foraminiferal genus. Orbulina d'Orbigny. Micropalaeontology, 2, 57-70.

Bolli, H., 1957. Planktonic Foraminifera from the Oligocene-Miocene Cipero and Lengua formations of Trinidad, B.W.I. U.S. Nat. Mus. Bull. 215, 97-124.

D. Graham Jenkins.

Department of Geology,

UNIVERSiTy COLLEGE OF WALES, ABERYSTWYTH.

31st August, 1958.

DEVELOPMENT OF LINEATION IN COMPLEX FOLD SYSTEMS

SiR,-Mr. P. A. Hill expresses the view in his letter (Geol. Mag., 1958, xcv, 351 ), that a paper (ibid., xciv, 1-24, 1957) by Clifford, Fleuty, Ramsay, Sutton, and Watson is, in parts, of " spurious accuracy", "statistically invalid"," "over-written ", and expressed in " jargon ". When 'Hill goes on to add "that these remarks are in some ways unfair, as they apply to many other workers" I am tempted to comment that perhaps we are all out of step except George.

"Spurious accuracy." Hill criticizes " dip symbols of $31^{\circ}, 59^{\circ}, 71^{\circ}$, etc." on our fig. 8 in the paper "a map of country where variation in dip is extreme". There are in fact no dip symbols on this map, but I will take it that Hill means structural observations in general. I had thought that the view that it was worthless to make accurate measurements in such ground was dying out. Rightly or wrongly our procedure has been to take large numbers of observations and to make each as accurate as we could. By doing this one can hope to find out whether there is system in the variations. Ramsay's field map of the ground covered by fig. 8 contains over 4,000 structural measurements. The analysis and presentation of such large masses of data raises problems. In the paper we used three methods of presentationstereograms (figs. 6, 10,11) ; sketch-maps showing generalized lines of strike with the directions of dip indicated (figs. $3,4,6,10$ ), or generalized directions of lineations (figs. 7, 10,11) ; maps showing observed values where there was some special reason for publishing these (fig. 8). One of the reasons for drawing fig. 8, criticized by Hill, was to show the distribution of two sets of linear structures, to demonstrate how one set survives near the axis of an early fold, but is largely destroyed on the limbs. It is disheartening to find that Hill, as a serious critic of the paper, states that these clearly labelled symbols for lineations represent dips of bedding planes or foliations.

Hill states that our fig. 10 is "statistically invalid". He claims that the distribution of 250 foliation readings shown on this figure is not given. The information appears, however, on p.16, lines 9-11. Hill also claims that the scatter of these readings is not shown. It is, however, shown by the stereogram, fig. 10b. This stereogram also indicates that the fold axis in the ground discussed by Fleuty is not bent in the manner Hill suggests. Although Hill has failed to grasp two of the facts shown by this stereogram he is content to end his letter with the ex cathedra remark (after no discussion of the matter at all) that stereographic projections are used as window dressing.

"Over-writing." Hill asks why 26 words are needed to say that a fold plunges steeply. This seems a reasonable question until one turns up the reference (p. 16, lines 1 and 2) and finds that the sentence says nothing about the amount of plunge but describes the form and attitude of a rather unusual fold. 